Jurnal Ekonomi Pembangunan

Volume 12, Nomor 1, Juni 2011, hlm.28-44

\title{
IDENTIFIKASI FAKTOR PENYEBAB KEMISKINAN DI KOTA SEMARANG DARI DIMENSI KULTURAL
}

\author{
Tri Wahyu Rejekiningsih \\ Fakultas Ekonomi Universitas Diponegoro Semarang \\ Jalan Erlangga Tengah Nomor 17 Semarang, Indonesia Telepon +62-24-8446409
}

Diterima 20 Februari 2011/Disetujui 5 Mei 2011

\begin{abstract}
This research is used to describe and identify the characteristics of poor people in Semarang. We select poor people from 4 villages in Semarang as sample, Bubakan, Krobokan, Genuksari, and Tandang village. In general, factors that cause poverty can be divided into 3 dimensions, natural, structural, and cultural factors. Poverty studies in this research will be analyzed by Cultural dimension approach. From the result we know that the characteristics of poor people in Semarang, are: most of the households' leaders are low educated (elementary graduated), work as labors, and have some responsibilities to three persons. Besides, we know that there is no equal level on support distribution to poor people. Related to the analysis from cultural dimensions, we know that in Semarang, poor people have cultural value orientations and positive behaviors to see the real life, real work, real time, and the connections between nature and human.
\end{abstract}

Keywords: poor people, cause poverty, characteristics of poor people, cultural dimensions

\begin{abstract}
Abstrak: Penelitian ini bertujuan mendeskripsikan dan mengidentifikasi karakteristik masyarakat miskin di kota Semarang. Sampel yang dipilih adalah masyarakat miskin di empat kelurahan di kota Semarang, yaitu: kelurahan Bubakan, kelurahan Krobokan, kelurahan Genuksari dan kelurahan Tandang. Secara umum faktor penyebab kemiskinan dapat dibagi menjadi tiga dimensi, yaitu faktor alam, struktural, dan kultural. Kajian kemiskinan dalam penelitian ini akan dianalisis melalui pendekatan dimensi kultural. Dari hasil penelitian diketahui bahwa karakteristik warga miskin di kota Semarang antara lain: kepala rumah tangga sebagian besar berpendidikan rendah (tamat SD), bekerja sebagai buruh, dan mempunyai tanggungan three jiwa. Selain itu diketahui bahwa terjadi adanya ketidakmerataan dalam distribusi bantuan kepada warga miskin. Terkait dengan analisis dari dimensi kultural diketahui bahwa warga miskin di kota Semarang memiliki orientasi nilai budaya dan sikap mental yang positif dalam memandang hakekat hidup, hakekat karya, hakekat waktu, hakekat hubungan dengan alam semesta dan sesama manusia.
\end{abstract}

Kata kunci: warga miskin, penyebab kemiskinan, karakterisik warga miskin, dimensi kultural

\section{PENDAHULUAN}

Kemiskinan adalah cross sectors problems, cross areas dan cross generation, sehingga untuk menanganinya dibutuhkan pendekatan yang terpa$\mathrm{du}$, komprehensif dan berkelanjutan. Untuk mensukseskan program percepatan penanggulangan kemiskinan dibutuhkan political will.

Perkembangan jumlah dan persentase pen- duduk miskin pada periode 1996 - 2007 tampak berfluktuasi dari tahun ke tahun meskipun terlihat adanya kecenderungan menurun pada periode 2000-2005 (Tabel. 1). Pada periode 19961999 jumlah penduduk miskin meningkat sebesar 13,96 juta orang karena krisis ekonomi, yaitu dari 34,01 juta orang pada tahun 1996 menjadi 47,97 juta orang pada tahun 1999. Sementara itu, persentase penduduk miskin mening- 
Tabel 1. Jumlah dan Persentase Penduduk Miskin di Indonesia Menurut Daerah 1996-2007

\begin{tabular}{lcccccc}
\hline \multirow{2}{*}{ Tahun } & \multicolumn{3}{c}{ Jumlah Penduduk Miskin (juta) } & \multicolumn{4}{c}{ Persentase Penduduk Miskin } \\
\cline { 2 - 6 } & Kota & Desa & Kota+Desa & Kota & Desa & Kota+Desa \\
\hline 1996 & 9,42 & 24,59 & 34,01 & 13,39 & 19,78 & 17,47 \\
1998 & 17,60 & 31,90 & 49,50 & 21,92 & 25,72 & 24,23 \\
1999 & 15,64 & 32,33 & 47,97 & 19,41 & 26,03 & 23,43 \\
2000 & 12,30 & 26,40 & 38,70 & 14,60 & 22,38 & 19,14 \\
2001 & 8,60 & 29,30 & 37,90 & 9,76 & 24,84 & 18,41 \\
2002 & 13,30 & 25,10 & 38,40 & 14,46 & 21,10 & 18,20 \\
2003 & 12,20 & 25,10 & 37,30 & 13,57 & 20,23 & 17,42 \\
2004 & 11,40 & 24,80 & 36,10 & 12,13 & 20,11 & 16,66 \\
2005 & 12,40 & 22,70 & 35,10 & 11,68 & 19,98 & 15,97 \\
2006 & 14,49 & 24,81 & 39,30 & 13,47 & 21,81 & 17,75 \\
2007 & 13,56 & 23,61 & 37,17 & 12,52 & 20,37 & 16,58 \\
\hline
\end{tabular}

Sumber: BPS, Analisis dan Penghitungan Tingkat Kemiskinan Tahun 2007, hal.42.

kat dari 17,47 persen menjadi 23,43 persen pada periode yang sama.

Pada periode 1999-2002 terjadi penurunan jumlah penduduk miskin sebesar 9,57 juta orang, yaitu dari 47,97 juta orang pada tahun 1999 menjadi 38,40 juta orang pada tahun 2002. Secara relatif juga terjadi penurunan persentase penduduk miskin pada periode yang sama.

Sekalipun sudah ada penurunan tetapi jumlahnya masih merupakan isu nasional, yaitu 13,56 juta orang penduduk miskin di perkotaan dan 23,61 juta orang penduduk miskin di pedesaan pada tahun 2007.

Tabel 2. Indeks Kedalaman Kemiskinan dan Indeks Keparahan Kemiskinan di Indonesia Menurut Daerah, Maret 2006 Maret 2007

\begin{tabular}{lccc}
\hline \multicolumn{1}{c}{ Tahun } & Kota & Desa & Kota+Desa \\
\cline { 1 - 1 }$\frac{\text { Indeks Kedalaman }}{\text { Kemiskinan }}$ & & & \\
$\frac{\text { Maret 2006 }}{\text { Maret 2007 }}$ & 2,61 & 4,22 & 3,43 \\
$\frac{\text { Indeks Keparahan }}{\text { Kemiskinan }}$ & 2,15 & 3,78 & 2,99 \\
$\frac{1,206}{\text { Maret 2006 }}$ & 0,77 & 1,22 & 1,00 \\
Maret 2007 & 0,57 & 1,09 & 0,84 \\
\hline
\end{tabular}

Sumber: BPS, Analisis dan Penghitungan Tingkat Kemiskinan Tahun 2007, hal.47.

Berdasarkan Tabel 2, pada periode Maret 2006 - Maret 2007, indeks kedalaman kemiskin- an dan indeks keparahan kemiskinan menunjukkan kecenderungan menurun. Penurunan nilai kedua indeks ini mengindikasikan bahwa rata-rata pengeluaran penduduk miskin cenderung makin mendekati garis kemiskinan dan ketimpangan pengeluaran penduduk miskin juga semakin menyempit.

Nilai indeks kedalaman kemiskinan dan indeks keparahan kemiskinan di daerah pedesaan jauh lebih tinggi dari pada perkotaan. Dapat disimpulkan bahwa tingkat kemiskinan di daerah pedesaan jauh lebih parah dari pada perkotaan.

Tabel 3. Gini Rasio di Indonesia Menurut Daerah, 1996 - 2007

\begin{tabular}{cccc}
\hline \multirow{2}{*}{ Tahun } & \multicolumn{3}{c}{ Gini Rasio } \\
\cline { 2 - 4 } & Kota & Desa & Kota+Desa \\
\hline 1996 & 0,362 & 0,274 & 0,356 \\
1999 & 0,326 & 0,244 & 0,311 \\
2002 & 0,330 & 0,290 & 0,329 \\
2005 & 0,338 & 0,264 & 0,343 \\
2006 & 0,350 & 0,276 & 0,357 \\
2007 & 0,374 & 0,302 & 0,376 \\
\hline
\end{tabular}

Sumber : BPS, Analisis dan Penghitungan Tingkat Kemiskinan Tahun 2007, hal.53

Secara umum angka gini rasio pada periode 1996-2007 di Indonesia berfluktuasi. Angka gini rasio ada kecenderungan menurun pada periode 1996-1999, namun kembali meningkat pada periode 1999-2007. Fluktuasi ang- 
ka Gini Rasio mengindikasikan adanya perubahan distribusi pengeluaran penduduk untuk melihat apakah pemerataan pengeluaran penduduk semakin baik atau semakin buruk. Pada periode 1996-1999 terjadi perbaikan distribusi pengeluaran penduduk sedangkan pada periode 1999-2007 justru distribusi pengeluaran penduduk di Indonesia semakin buruk (Tabel $3)$.

Dilihat menurut daerah angka gini rasio, tingkat ketimpangan pengeluaran penduduk di perkotaan relatif lebih tinggi dibandingkan dengan di perdesaan. Pola perubahan distribusi pengeluaran penduduk di perkotaan dan pedesaan tidak selalu linier. Terlihat pada Tabel 3 bahwa angka gini rasio pada periode 2002-2005 di perkotaan meningkat sementara di pedesaan justru menurun.

Secara nasional jumlah penduduk miskin pada tahun 2009 masih relatif tinggi sekitar 32,53 juta jiwa atau 14,15 persen, yang tersebar di perkotaan sebanyak 11,91 juta atau dibulatkan menjadi 12 juta orang, atau sebesar 10,72 persen dan untuk di pedesaan dua kali lipat dari jumlah itu, 20,62 juta jiwa atau dibulatkan menjadi 21 juta jiwa atau 17,35 persen. Begitu pula angka pengangguran yang masih relatif tinggi 9,26 juta atau sebesar 8,14 persen (BPS,
2009). Kondisi seperti ini tentunya akan dapat menjadi beban dalam upaya pembangunan yang dilaksanakan di Indonesia. Hal ini dikarenakan pekerjaan rumah (PR) untuk mengentaskan kemiskinan masih tetap menjadi tantangan yang belum dapat dijawab dengan baik, meskipun telah dikembangkan berbagai modal bantuan keuangan yang notabene ditujukan untuk meningkatkan modal keuangan masyarakat.

Dalam lima tahun terakhir saja, programprogram pengentasan kemiskinan seperti P2KP (Program Penanggulangan Kemiskinan Perkotaan), PPMK (Program Pemberdayaan Masyarakat Kelurahan), Program Pinjaman Modal Usaha dari berbagai departemen dan juga lembaga swadaya masyarakat telah diluncurkan, tetapi hasilnya angka penduduk yang berada di bawah garis kemiskinan (\$2 per hari per kepala) tetap masih besar.

Pemerintah pusat maupun daerah tidak henti untuk menurunkan angka kemiskinan dan pengangguran dengan perbaikan kondisi sosial, ekonomi, dan sosial budaya serta adanya upaya peningkatan kesejahteraan masyarakat miskin. Untuk mencapai harapan itu pemerintah daerah Kota Semarang telah menetapkan empat kelurahan percontohan penanggulangan kemiskinan, yaitu Kelurahan Bubakan, Kelu-

Tabel 4. Jumlah Rumah Tangga Miskin di Kota Semarang

\begin{tabular}{|c|c|c|c|c|c|c|c|}
\hline \multirow[t]{3}{*}{ No } & \multirow[t]{3}{*}{ Kecamatan } & \multicolumn{6}{|c|}{ Jenis Kelamin Kepala Keluarga Rumah Tangga } \\
\hline & & \multicolumn{3}{|c|}{2006} & \multicolumn{3}{|c|}{2008} \\
\hline & & Laki-Laki & Perempuan & Total & Laki-Laki & Perempuan & Total \\
\hline 1 & Mijen & 3.100 & 1.012 & 4.112 & 1.959 & 640 & 2.599 \\
\hline 2 & Gunung Pati & 4.927 & 1.319 & 6.246 & 3.693 & 989 & 4.682 \\
\hline 3 & Banyumanik & 3.412 & 1.037 & 4.449 & 2.963 & 914 & 3.877 \\
\hline 4 & Gajah Mungkur & 1.665 & 598 & 2.263 & 1.067 & 524 & 1.591 \\
\hline 5 & Semarang Selatan & 3.124 & 1.275 & 4.399 & 2.138 & 872 & 3.010 \\
\hline 6 & Candisari & 3.146 & 1.158 & 4.304 & 1.323 & 534 & 1.857 \\
\hline 7 & Tembalang & 5.963 & 1.930 & 7.893 & 3.584 & 1.164 & 4.748 \\
\hline 8 & Pedurungan & 4.227 & 1.389 & 5.616 & 2.153 & 710 & 2.863 \\
\hline 9 & Genuk & 4.142 & 1.344 & 5.486 & 3.036 & 995 & 4.031 \\
\hline 10 & Gayamsari & 3.872 & 1.050 & 4.922 & 2.393 & 646 & 3.039 \\
\hline 11 & Semarang Timur & 3.532 & 1.664 & 5.196 & 3.180 & 1.492 & 4.672 \\
\hline 12 & Semarang Utara & 5.887 & 2.299 & 8.186 & 3.762 & 1.476 & 5.238 \\
\hline 13 & Semarang Tengah & 2.351 & 1.377 & 3.728 & 1.885 & 1.096 & 2.981 \\
\hline 14 & Semarang Barat & 6.301 & 1.958 & 8.259 & 4.676 & 1.467 & 6.143 \\
\hline 15 & Tugu & 1.939 & 692 & 2.631 & 1.015 & 515 & 1.530 \\
\hline \multirow[t]{2}{*}{16} & Ngaliyan & 3.756 & 1.219 & 4.975 & 2.387 & 780 & 3.167 \\
\hline & Total & 61.344 & 21.321 & 82.665 & 41.214 & 14.814 & 56.028 \\
\hline
\end{tabular}

Sumber: BPS Kota Semarang, Profil Rumah Tangga Miskin Kota Semarang. 
Tabel 5. Jumlah Rumah tangga Miskin Pada Kelurahan Percontohan

\begin{tabular}{|c|c|c|c|c|c|c|c|}
\hline \multirow[t]{3}{*}{ No } & \multirow[t]{3}{*}{ Kelurahan } & \multicolumn{6}{|c|}{ Jenis Kelamin Kepala Rumah tangga } \\
\hline & & \multicolumn{3}{|c|}{2006} & \multicolumn{3}{|c|}{2008} \\
\hline & & Laki-laki & Perempuan & $\begin{array}{l}\text { Total } \\
\text { (KK) }\end{array}$ & Laki-laki & Perempuan & $\begin{array}{l}\text { Total } \\
\text { (KK) }\end{array}$ \\
\hline 1 & Bubakan & 119 & 37 & 156 & 75 & 24 & 99 \\
\hline 2 & Tandang & 1.567 & 487 & 2.054 & 996 & 309 & 1.305 \\
\hline 3 & Genuksari & 563 & 234 & 797 & 438 & 182 & 620 \\
\hline 4 & Krobokan & 569 & 211 & 780 & 399 & 148 & 547 \\
\hline
\end{tabular}

Sumber: BPS Kota Semarang, Profil Rumah Tangga Miskin Kota Semarang.

rahan Tandang, Kelurahan Genuksari dan Kelurahan Krobokan. Keempat kelurahan tersebut tersebar pada empat kecamatan yang memiliki jumlah rumah tangga miskin besar, yaitu berturut-turut Kecamatan Mijen, Kecamatan Tembalang, Kecamatan Genuk dan Kecamatan Semarang Barat (Tabel 4).

Empat kelurahan percontohan tersebut, merupakan kelurahan yang mengalami penurunan jumlah rumah tangga miskin yang relatif lebih banyak dibandingkan dengan kelurahan lainnya pada kecamatan yang sama. Pada tahun 2006 Kelurahan Bubakan memiliki jumlah rumah tangga miskin sekitar 3,79 persen (156 KK) dari total jumlah rumah tangga miskin yang ada di Kecamatan Mijen, sedangkan Kelurahan Tandang sebanyak 26,02 persen (2.054 KK) dari total rumah tangga miskin di Kecamatan Tembalang. Kelurahan Genuksari dan Krobokan memiliki sekitar 14,53 persen (797 KK) dan 9,44 persen (780 KK), masing-masing dari total rumah tangga miskin yang ada di Kecamatan Genuk dan Semarang Barat. Pada tahun 2008 persentase jumlah rumah tangga miskin masing-masing kelurahan tersebut me- ngalami penurunan sekitar berturut-turut 36,54 persen; 36,47 persen; 22,21 persen dan 29,87 persen. Secara keseluruhan, jumlah rumah tangga miskin di Kota Semarang selama periode tahun 2006-2008 mengalami penurunan sekitar 32,22 persen, yaitu dari 82.665 KK menjadi $56.028 \mathrm{KK}$. Meskipun jumlah rumah tangga miskin mengalami penurunan selama periode tahun 2006-2008, namun di sisi lain jumlah rumah tangga dari keempat kelurahan percontohan mengalami kenaikan (Tabel 6).

Pembahasan terhadap faktor penyebab kemiskinan didasarkan pada aspek mental manusia, hal ini dikategorikan sebagai faktor endogen penyebab kemiskinan. Sistem nilai budaya dan sikap merupakan faktor-faktor mental yang menyebabkan timbulnya pola-pola berpikir tertentu pada warga masyarakat, terutama warga miskin. Pola-pola berpikir ini kemudian mempengaruhi tindakan dan kelakuan masyarakat, baik dalam kehidupan sehari-hari, maupun dalam membuat keputusan-keputusan yang penting dalam hidup.

Upaya perbaikan kesejahteraan rakyat perlu ditopang dengan perbaikan sikap mental

Tabel 6. Jumlah Rumah tangga pada Kelurahan Percontohan

\begin{tabular}{llrrrr}
\hline \multirow{2}{*}{ No } & Kelurahan & \multicolumn{2}{c}{ 2006 } & \multicolumn{2}{c}{ 2008 } \\
\cline { 3 - 6 } & & RT (KK) & $\Delta$ RT Miskin (\%) & RT (KK) & $\Delta$ RT Miskin (\%) \\
\hline 1 & Bubakan & 658 & 23,71 & 700 & 14,14 \\
2 & Tandang & 4.988 & 41,18 & 5.015 & 26,02 \\
3 & Genuksari & 2.519 & 31,64 & 2.706 & 22,91 \\
4 & Krobokan & 2.503 & 31,16 & 2.449 & 22,34 \\
\hline
\end{tabular}

Sumber: BPS Kota Semarang, Kota Semarang dalam Angka 
masyarakat. Sikap mental juga dapat menjadi salah satu penyebab timbulnya kemiskinan pada diri seseorang atau sekelompok masyarakat. Oleh karena itu tujuan dari penelitian ini adalah: (1) Mendiskripsikan masyarakat miskin dalam kajian kultural, (2) Mengidentifikasikasi karakteristik kemiskinan di daerah penelitian.

Konsep Kemiskinan. Secara etimologis, "kemiskinan" berasal dari kata "miskin" yang artinya tidak berharta benda dan serba kekurangan. Departemen Sosial dan Badan Pusat Statistik mendefinisikan kemiskinan dari perspektif kebutuhan dasar. Kemiskinan didefinisikan sebagai ketidakmampuan individu dalam memenuhi kebutuhan dasar minimal untuk hidup layak (BPS dan Depsos, 2002). Lebih jauh disebutkan kemiskinan merupakan sebuah kondisi yang berada di bawah garis nilai standar kebutuhan minimum, baik untuk makanan dan nonmakanan yang disebut garis kemiskinan (poverty line) atau batas kemiskinan (poverty treshold).

Konsep kemiskinan dapat dibedakan menjadi dua, yaitu kemiskinan absolut dan kemiskinan relatif. David Harry Penny (1990) mendefinisikan kemiskinan absolut dalam kaitannya dengan suatu sumber-sumber materi, yang di bawahnya tidak ada kemungkinan kehidupan berlanjut; dengan kata lain hal ini adalah tingkat kelaparan. Sedangkan kemiskinan relatif adalah perhitungan kemiskinan yang didasarkan pada proporsi distribusi pendapatan dalam suatu negara. World Bank (BPS, 2003) menyusun ukuran kemiskinan relatif yang sekaligus digunakan untuk mengukur tingkat pemerataan, yaitu dengan membagi penduduk menjadi tiga kelompok: (1) kelompok 40 persen penduduk berpendapatan rendah, (2) 40 persen penduduk berpendapatan menengah, dan (3) 20 persen penduduk berpendapatan tinggi.

Untuk menentukan ukuran kemiskinan bukanlah hal yang mudah. Kesulitan tersebut bukan hanya pada indikator apa yang akan digunakan, tetapi juga bagaimana menggunakan indikator tersebut pada suatu individu, keluarga, kelompok orang atau masyarakat. Untuk mempermudah bagaimana mengukur kemiskinan tersebut, kemudian muncul konsep poverty line (garis kemiskinan).

Ada banyak teori tentang kemiskinan, namun menurut Michael Sherraden (Arif, 2009) dapat dikelompokkan ke dalam dua kategori yang saling bertentangan dan satu kelompok teori yang tidak memihak (middle ground), yaitu teori yang memfokuskan pada tingkah laku individu (behavioral), teori yang mengarah pada struktur sosial, dan yang satu teori mengenai budaya miskin. Menurutnya, teori yang memfokuskan pada tingkah laku individu merupakan teori tentang pilihan, harapan, sikap, motivasi dan kapital manusia (human capital). Teori ini disajikan dalam teori ekonomi neoklasik, yang berasumsi bahwa manusia bebas mengambil keputusan untuk dirinya sendiri dengan tersedianya pilihan-pilihan. Perspektif ini sejalan dengan teori sosiologi fungsionalis, bahwa ketidaksetaraan itu tidak dapat dihindari dan diinginkan adalah keniscayaan dan penting bagi masyarakat secara keseluruhan. Teori perilaku individu meyakini bahwa sikap individu yang tidak produktif telah mengakibatkan lahirnya kemiskinan.

Teori Struktural yang bertolak belakang dengan teori perilaku memandang bahwa hambatan-hambatan struktural yang sistematik telah menciptakan ketidaksamaan dalam kesempatan, dan berkelanjutannya penindasan terhadap kelompok miskin oleh kelompok kapitalis. Variasi teori struktural ini terfokus pada topik seperti ras, gender atau ketidak sinambungan geografis dalam kaitannya atau dalam ketidakterkaitannya dengan ras.

Teori budaya miskin yang dikembangkan oleh Oscar Lewis dan Edward Banfield ini mengatakan bahwa gambaran budaya kelompok kelas bawah, khususnya pada orientasi untuk masa sekarang dan tidak adanya penundaan atas kepuasan, mengekalkan kemiskinan di kalangan mereka dari satu generasi ke generasi berikutnya.

Menurut Michael Sherraden bahwa dalam berbagai bentuk, teori budaya miskin ini berakar pada politik sayap kiri (Lewis) dan politik sayap kanan (Banfield). Dari sayap kiri, perspektif ini dikenal sebagai situasi miskin, yang mengindikasikan bahwa adanya disfungsi tingkah laku ternyata merupakan adaptasi fungsional terhadap keadaan-keadaan yang sulit (Arif, 2009). Dengan kata lain kelompok sayap kiri cenderung melihat budaya miskin sebagai sebuah akibat dari struktur sosial. Sebaliknya 
kelompok sayap kanan melihat tingkah laku dan budaya masyarakat kelas bawah yang mengakibatkan mereka menempati posisi di bawah dalam struktur sosial.

Pendekatan Masalah Kemiskinan. Ada dua pendekatan yang dapat digunakan dalam studi tentang kemiskinan, yaitu pendekatan obyektif dan pendekatan subyektif. Pendekatan obyektif yaitu pendekatan dengan menggunakan ukuran kemiskinan yang telah ditentukan oleh pihak lain terutama para ahli yang diukur dari tingkat kesejahteraan sosial sesuai dengan standar kehidupan. Pendekatan subyektif adalah pendekatan dengan menggunakan ukuran kemiskinan yang ditentukan oleh orang miskin itu sendiri yang diukur dari tingkat kesejahteraan sosial dari orang miskin dibandingkan dengan orang kaya yang ada dilingkungannya. Seperti diungkapkan oleh Joseph F. Stepanek (Arif, 2009) bahwa pendekatan subyektif menilai kemiskinan berdasarkan pendapat atau pandangan orang miskin sendiri.

Pendekatan kebutuhan dasar, melihat bahwa kemiskinan sebagai suatu ketidakmampuan (lack of capabilities) seseorang, keluarga dan masyarakat dalam memenuhi kebutuhan minimum, antara lain pangan, sandang, papan, pelayanan kesehatan, pendidikan, penyediaan air bersih, dan sanitasi.

Sedangkan pendekatan pendapatan, melihat bahwa kemiskinan disebabkan oleh rendahnya penguasaan aset, dan alat-alat produktif seperti tanah dan lahan pertanian atau perkebunan, sehingga secara langsung mempengaruhi pendapatan seseorang dalam masyarakat. Pendekatan ini, menentukan secara rigid standar pendapatan seseorang di dalam masyarakat untuk membedakan kelas sosialnya. Demikian pula pendekatan kemampuan dasar yang menilai bahwa kemiskinan sebagai keterbatasan kemampuan dasar seperti kemampuan membaca dan menulis untuk menjalankan fungsi minimal dalam masyarakat.

Berbeda dengan pendekatan di atas, pendekatan hak melihat bahwa kemiskinan didefinisikan sebagai kondisi di mana seseorang atau sekelompok orang, laki-laki dan perempuan, tidak terpenuhi hak-hak dasarnya untuk mempertahankan dan mengembangkan kehidupan yang bermartabat. Hak-hak dasar yang diakui secara umum antara lain meliputi terpenuhinya kebutuhan pangan, kesehatan, pendidikan, pekerjaan, perumahan, air bersih, pertanahan, sumberdaya alam dan lingkungan hidup, rasa aman dari perlakukan atau ancaman tindak kekerasan dan hak untuk berpartisipasi dalam kehidupan sosial-politik, baik bagi perempuan maupun laki-laki.

Kemiskinan Relatif. Kemiskinan relatif merupakan kondisi miskin karena pengaruh kebijakan pembangunan yang belum mampu menjangkau seluruh lapisan masyarakat sehingga menyebabkan ketimpangan distribusi pendapatan. Standar minimum disusun berdasarkan kondisi hidup suatu negara pada waktu tertentu dan perhatian terfokus pada golongan penduduk "termiskin" misalnya 20 persen atau 40 persen lapisan terendah dari total penduduk yang telah diurutkan menurut pendapatan/ pengeluarannya. Kelompok ini merupakan penduduk relatif miskin. Dengan demikian, ukuran kemiskinan relatif sangat tergantung pada distribusi pendapatan/pengeluaran penduduk sehingga dengan menggunakan definisi ini berarti "orang miskin selalu hadir bersama kita".

Dalam praktek, negara kaya mempunyai garis kemiskinan relatif yang lebih tinggi dari pada negara miskin seperti pernah dilaporkan oleh Ravallion (1998). Dalam hal mengidentifikasi dan menentukan sasaran penduduk miskin, maka garis kemiskinan relatif cukup untuk digunakan, dan perlu disesuaikan terhadap tingkat pembangunan negara secara keseluruhan. Garis kemiskinan relatif tidak dapat dipakai untuk membandingkan tingkat kemiskinan antarnegara dan waktu karena tidak mencerminkan tingkat kesejahteraan yang sama.

Kemiskinan Absolut. Kemiskinan secara absolut ditentukan berdasarkan ketidakmampuan untuk mencukupi kebutuhan pokok minimum seperti pangan, sandang, kesehatan, perumahan dan pendidikan yang diperlukan untuk bisa hidup dan bekerja. Kebutuhan pokok minimum diterjemahkan sebagai ukuran finansial dalam bentuk uang. Nilai kebutuhan minimum berupa kebutuhan dasar dan dikenal dengan istilah garis kemiskinan. Penduduk yang pendapatannya di bawah garis kemiskinan digolongkan sebagai penduduk miskin. Ga- 
ris kemiskinan absolut "tetap (tidak berubah)" dalam hal standar hidup. Garis kemiskinan absolut mampu membandingkan kemiskinan secara umum.

Ciri-Ciri yang Melekat pada Penduduk Miskin. Beberapa ciri yang melekat pada penduduk miskin yaitu: (1) Pendapatan masih rendah atau tidak berpendapatan, (2) Tidak memiliki pekerjaan tetap, (3) Pendidikan rendah bahkan tidak berpendidikan, (4) Tidak memiliki tempat tinggal, (5) Tidak terpenuhinya standar gizi minimal.

Penyebab Kemiskinan. Kemiskinan Struktural adalah kemiskinan yang disebabkan dari kondisi struktur, atau tatanan kehidupan yang tak menguntungkan (Soetandyo, 1995). Dikatakan tak menguntungkan karena tatanan itu tidak hanya menerbitkan akan tetapi juga melanggengkan kemiskinan di dalam masyarakat.

Kemiskinan kultural diakibatkan oleh faktor-faktor adat dan budaya suatu daerah tertentu yang membelenggu seseorang tetap melekat dengan indikator kemiskinan (Suyanto, 1995). Padahal indikator kemiskinan tersebut seyogyanya bisa dikurangi atau bahkan secara bertahap bisa dihilangkan dengan mengabaikan faktor-faktor adat dan budaya tertentu yang menghalangi seseorang melakukan perubahan-perubahan ke arah tingkat kehidupan yang lebih baik.

Kemiskinan Menurut BKKBN. BKKBN membagi kriteria keluarga ke dalam lima tahapan, yaitu Keluarga Pra Sejahtera (Pra-KS), Keluarga
Sejahtera I (KS I), Keluarga Sejahtera II (KS II), Keluarga Sejahtera III (KS III) dan Keluarga Sejahtera III Plus (KS III-Plus).

Menurut BKKBN kriteria keluarga yang dikategorikan sebagai keluarga miskin adalah Keluarga Pra Sejahtera (Pra-KS) dan Keluarga Sejahtera I (KS I). Ada lima indikator yang harus dipenuhi agar suatu keluarga dikategorikan sebagai Keluarga Sejahtera I, yaitu: (1) Anggota keluarga melaksanakan ibadah sesuai agama yang dianut masing-masing, (2) Seluruh anggota keluarga pada umumnya makan dua kali sehari atau lebih, (3) Seluruh anggota keluarga mempunyai pakaian yang berbeda di rumah, sekolah, bekerja, dan bepergian, (4) Bagian terluas lantai rumah bukan dari tanah, (5) Bila anak sakit atau Pasangan Usia Subur (PUS) ingin mengikuti KB pergi ke sarana/ petugas kesehatan serta diberi cara KB modern.

Keluarga Pra Sejahtera adalah keluargakeluarga yang tidak memenuhi salah satu dari lima indikator tersebut di atas. Pendekatan BKKBN ini dianggap masih kurang realistis karena konsep Keluarga Pra Sejahtera dan KS I sifatnya normatif dan lebih sesuai dengan keluarga kecil/inti, di samping kelima indikator tersebut masih bersifat sentralistik dan seragam yang belum tentu relevan dengan keadaan dan budaya lokal.

Kemiskinan Menurut BPS. Pada tahun 2000 BPS melakukan studi Penentuan Kriteria Penduduk Miskin (SPKPM 2000) untuk mengetahui karakteristik-karakteristik rumah tangga

Tabel 7. Delapan Variabel hasil SPKPM 2000

\begin{tabular}{|c|c|c|c|}
\hline \multirow[t]{2}{*}{ No } & \multirow[t]{2}{*}{ Variabel } & \multicolumn{2}{|c|}{ Skor } \\
\hline & & Skor 1 & Skor 0 \\
\hline 1 & Luas lantai per kapita & $<=8 \mathrm{~m}^{2}$ & $>8 \mathrm{~m}^{2}$ \\
\hline 2 & Jenis lantai & Tanah & Bukan tanah \\
\hline 3 & $\begin{array}{l}\text { Air Minum/Ketersediaan air } \\
\text { bersih }\end{array}$ & $\begin{array}{l}\text { Air hujan/sumur tidak } \\
\text { terlindung }\end{array}$ & $\begin{array}{l}\text { Ledeng/PAM/sumur } \\
\text { terlindung }\end{array}$ \\
\hline 4 & Jenis jamban/WC & Tidak ada & Bersama/Sendiri \\
\hline 5 & Kepemilikan Asset & Tidak punya asset & Punya asset \\
\hline 6 & $\begin{array}{l}\text { Pendapatan (total pendapatan per } \\
\text { bulan) }\end{array}$ & $<=$ Rp. $350.000,0$ & $>$ Rp. $350.000,0$ \\
\hline 7 & $\begin{array}{l}\text { Pengeluaran (persentase } \\
\text { pengeluaran untuk makanan) }\end{array}$ & 80 persen + & $<80$ persen \\
\hline 8 & $\begin{array}{l}\text { Konsumsi lauk pauk (daging, ikan, } \\
\text { telur, ayam) }\end{array}$ & $\begin{array}{l}\text { Tidak ada/ ada, tapi } \\
\text { tidak bervariasi }\end{array}$ & Ada, bervariasi \\
\hline
\end{tabular}

Sumber: BPS, Analisis dan Penghitungan Tingkat Kemiskinan Tahun 2007, hal.17. 
yang mampu mencirikan kemiskinan secara konseptual. Dari hasil SPKPM 2000, diperoleh delapan variabel yang dianggap layak dan operasional untuk penentuan rumah tangga miskin di lapangan. Skor 1 mengacu kepada sifat-sifat yang mencirikan kemiskinan dan skor 0 mengacu kepada sifat-sifat yang mencirikan ketidakkemiskinan.

Skor batas yang digunakan adalah 5 (lima) yang didasarkan atas modus total skor dari domain rumah tangga miskin secara konseptual. Dengan demikian apabila suatu rumah tangga mempunyai minimal 5 (lima) ciri miskin maka rumah tangga tersebut digolongkan sebagai rumah tangga miskin.

Pengertian, Ukuran dan Faktor Penyebab Kemiskinan. Banyak pengertian yang diberikan para ahli mengenai kemiskinan. Ada yang memandang kemiskinan dari sisi material, atau non material, namun ada pula yang memandang dari kedua sisi tersebut. Ukuran kemiskinan pun menjadi sangat relatif sekali, seperti halnya pengertian tentang kemiskinan tersebut. Masing-masing orang memiliki ukuran yang berbeda. Sebagai contoh: ukuran miskin seorang petani akan sangat berbeda dengan ukuran miskin seorang pengusaha. Perbedaan ukuran ini terutama jika kemiskinan itu dipandang berdasarkan subyeknya. Akan tetapi, jika kemiskinan tersebut dipandang dari obyeknya, ukurannya menjadi relatif sama yaitu ukuran yang mendasarkan pada terpenuhinya kebutuhan dasar minimum manusia.

Abraham Maslow (1984) membagi kebutuhan manusia ke dalam 5 jenjang kebutuhan, yaitu: (1) Kebutuhan fisiologis seperti makan, minum, tempat berteduh, kesehatan, dan lainlain, (2) Kebutuhan akan rasa aman, tenteram, bebas dari rasa takut, jaminan keselamatan, mendapat pekerjaan, serta adanya peraturan yang memberikan bimbingan dan pengarahan untuk bertindak, (3) Kebutuhan akan rasa memiliki, diakui dan diterima oleh lingkungannya, cinta-mencintai, dan kebutuhan sosial lainnya, (4) Kebutuhan akan karya diri dan prestasi, (5) Kebutuhan akan aktualisasi diri. Berdasarkan jenjang kebutuhan manusia tersebut, seseorang dapat dikatakan miskin jika kebutuhan fisiologi belum terpenuhi atau belum memenuhi standar minimum kebutuhan manusia.
Sajogyo (1977) mendefinisikan kemiskinan sebagai suatu tingkat kehidupan yang berada di bawah standar minimum yang ditetapkan berdasarkan atas kebutuhan pokok pangan yang membuat orang cukup bekerja dan hidup sehat, berdasar atas kebutuhan beras dan kebutuhan gizi. Pengukuran Sajogyo (1988) dalam membuat batasan kemiskinan di pedesaan didasarkan pada patokan cukup 1.900 kalori dan 40 gram protein per orang per hari. Ukuran tersebut dinyatakan dalam pengeluaran setara satuan kilogram beras per orang per tahun yaitu: (1) Miskin sekali=kurang dari 240 kilogram, (2) Miskin=240 sampai 320 kilogram, (3) Nyaris miskin $=320$ sampai 480 kilogram.

Sementara itu faktor penyebab kemiskinan secara umum dibedakan menjadi dua yaitu faktor eksogen dan endogen. Faktor eksogen (faktor yang berada di luar individu tersebut) dibedakan menjadi faktor alamiah (keadaan alam, iklim, dan bencana alam) dan faktor buatan atau struktur (kolonialisme, sifat pemerintahan, sistem ekonomi dan sebagainya). Sedangkan faktor endogen (faktor yang berasal dari dalam individu itu sendiri) misalnya sifat fatalis, malas, boros, konformis, dan sebagainya. Pembagian faktor penyebab kemiskinan ini merupakan kesimpulan dari pendapat beberapa ahli seperti: Bayo Ala (1981), Ndaru Mursito (1981), Koentjaraningrat (1983), Geertz (1983) dan Scoot (1983).

Pembagian Orientasi Nilai Budaya dan Sikap Mental. Koentjaraningrat (1983) menyatakan sistem nilai budaya merupakan tingkat yang paling abstrak dari suatu adat-istiadat. Hal tersebut terdiri dari konsepsi-konsepsi yang hidup dalam alam pikiran sebagian besar warga masyarakat, sehingga nilai budaya tersebut merupakan hal-hal yang harus dianggap amat bernilai dalam hidup. Oleh karena itu sistem nilai budaya umumnya berfungsi sebagai pedoman tertinggi bagi kelakuan manusia. Lebih lanjut koentjaraningrat mengartikan sikap mental sebagai suatu disposisi atau keadaan mental di dalam jiwa dan diri seorang individu untuk bereaksi terhadap lingkungannya, baik lingkungan manusia, alam maupun fisik.

Sementara itu, Kluckhohn dalam Koentjaraningrat (1983) menyatakan bahwa sistem nilai 


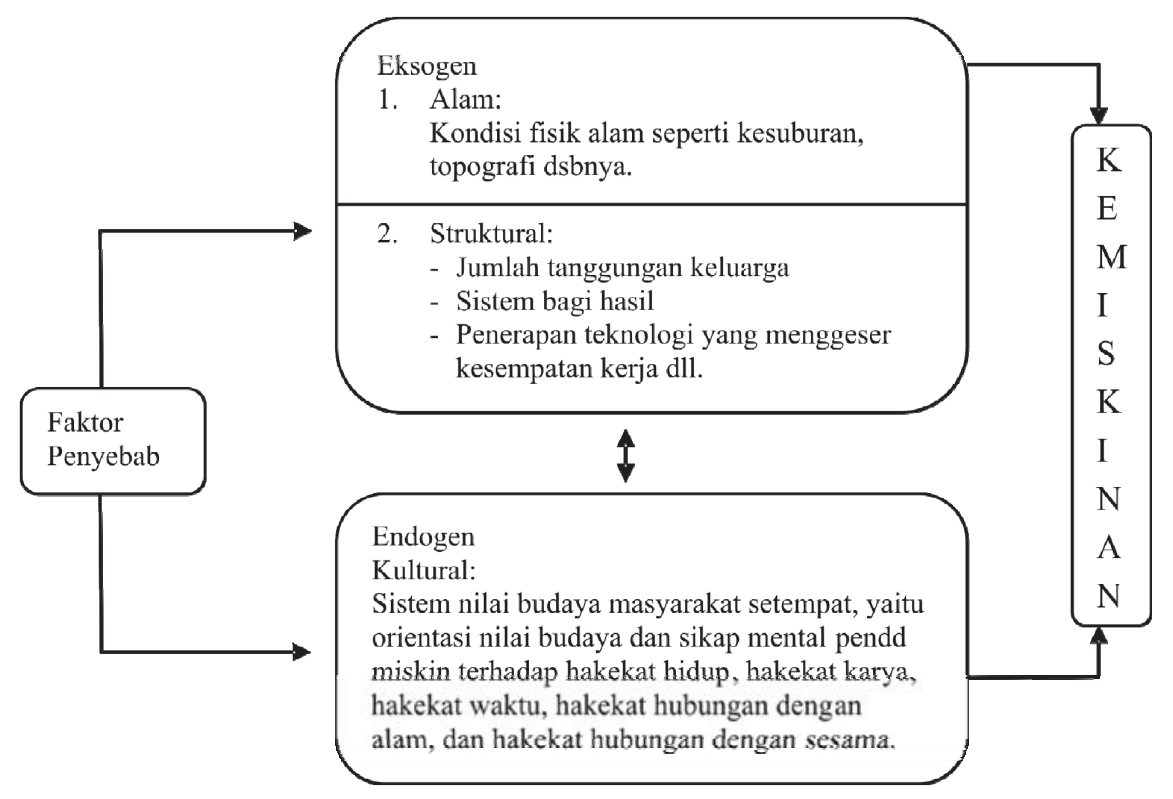

Gambar 1. Kerangka Pemikiran

budaya dalam semua kebudayaan di dunia menyangkut lima masalah dasar dalam kehidupan manusia, yaitu: menyangkut hakekat hidup manusia, hakekat karya manusia, hakekat waktu, hubungan manusia dengan alam, dan hubungan manusia dengan manusia lainnya. Kelima masalah pokok tersebut memiliki orientasi nilai budaya yang masing-masing "melahirkan" suatu sikap mental. Sikap mental tersebut bisa sejalan atau tidak sejalan dengan upaya peningkatan taraf hidup warga miskin.

Kerangka Pemikiran. Sikap mental dapat menjadi salah satu penyebab timbulnya kemiskinan pada diri seseorang atau sekelompok masyarakat. Sikap mental semacam ini disebut juga sikap mental negatif, yaitu yang tidak sejalan dengan upaya peningkatan taraf hidupnya. Dalam penelitian ini mencoba menjelaskan hubungan antara orientasi nilai-nilai budaya dan sikap mental penduduk miskin terhadap lima masalah dasar manusia yaitu hakekat hidup, hakekat waktu, hakekat karya, hakekat hubungan dengan alam, dan hakekat hubungan dengan sesama. Kelima masalah mendasar tersebut diduga merupakan salah satu faktor penyebab kemiskinan (Gambar 1).

\section{METODE PENELITIAN}

\section{Definisi Operasional Variabel}

Berdasarkan per definisi bahwa kemiskinan ditentukan karena ketidakmampuan untuk mencukupi kebutuhan pokok minimum seperti pangan, sandang, kesehatan, perumahan dan pendidikan yang diperlukan untuk bisa hidup dan bekerja. Untuk memudahkan analisis, maka pemilihan warga miskin berdasarkan data warga miskin di setiap kelurahan yang telah menerima dan memanfaatkan bantuan dari program penanggulangan kemiskinan di kota Semarang.

Adapun jenis bantuan dari program penanggulangan kemiskinan di Kota Semarang yang telah diterima dan dimanfaatkan oleh warga miskin adalah sebagai berikut: Askeskin, Jamkesmas, BLT, Raskin, P2KP-BKM, Konversi Minyak Tanah ke LPG, PNPM Mandiri, UEDSP, GPS dan Sembako (Bapermas Kota Semarang, 2009).

\section{Jenis Data}

Data yang digunakan dalam kajian ini meliputi data sekunder dan data primer. Data sekunder 
diperoleh dari Badan Pemberdayaan Masyarakat Perempuan dan Keluarga Berencana Kota Semarang, BPS Provinsi Jawa Tengah, publikasi yang dikeluarkan lembaga-lembaga tertentu yang relevan serta kajian pustaka. Data sekunder yang diperlukan di antaranya seperti data profil warga miskin yang menerima dan memanfaatkan bantuan dari program penangguslangan kemiskinan kota Semarang. Data sekunder diambil dari bahan pustaka yang berkaitan dengan kemiskinan dan kebudayaan.

Data primer diperoleh dari hasil survei dengan menggunakan kuesioner yang dilakukan terhadap warga miskin pada kelurahankelurahan yang dipilih sebagai sampel di Kota Semarang. Pengambilan sampel dilakukan secara acak sederhana terhadap warga miskin yang ada di kelurahan sampel tersebut.

\section{Jumlah Sampel}

Total populasi yang dijadikan obyek penelitian ini adalah sebanyak 2.571 rumah tangga miskin (Tabel 5). Penentuan jumlah sampel yang diambil menggunakan rumus Slovin:

$\mathrm{n}=\mathrm{N} /\left(1+\mathrm{Ne}^{2}\right)$

dimana $\mathrm{n}$ adalah besaran sampel, $\mathrm{N}$ adalah besaran populasi, e adalah nilai kritis (batas ketelitian) yang diinginkan (persen kelonggaran ketidaktelitian karena kesalahan penarikan sampel) dan besarnya nilai tersebut adalah 10 persen.

Tabel 8. Jumlah Responden pada Setiap Kelurahan yang Diamati (Rumah tangga Miskin)

\begin{tabular}{llrr}
\hline No & Kelurahan & Jumlah & \multicolumn{2}{c}{$\begin{array}{c}\text { Jumlah } \\
\text { Responden }\end{array}$} \\
\hline 1 & Bubakan & 99 & 4 \\
2 & Tandang & 1.305 & 51 \\
3 & Genuksari & 620 & 24 \\
4 & Krobokan & 547 & 21 \\
\hline & & 2571 & 100 \\
\hline
\end{tabular}

Nilai kritis 10 persen dipilih karena, merupakan batas nilai maksimal kelonggaran yang masih dapat ditoleransi. Jadi besarnya sampel yang akan diambil adalah sebesar:

$\mathrm{n}=2571 /\left(1+2571(0,1)^{2}\right)=2571 / 26,71=96,256$

(dibulatkan menjadi 100 orang). Jumlah sampel sebanyak 100 orang tersebut berasal dari keempat kelurahan yang dipilih sebagai daerah penelitian.

Data orientasi nilai budaya dan sikap mental responden diolah dengan skala likert, disajikan dalam bentuk persentase dan tabulasi, yang pada akhirnya dianalisis secara deskriptif.

\section{HASIL DAN PEMBAHASAN}

\section{Gambaran Umum Responden}

Dari kelurahan-kelurahan yang dijadikan sampel penelitian (Tabel 9), maka diketahui bahwa 34 persen responden berjenis kelamin perempuan dan 66 persennya laki-laki. Semua respondennya laki-laki untuk kelurahan Bubakan, Krobokan dan Genuksari, sedangkan kelurahan Tandang ada 17 orang laki-laki dan 34 orang perempuan.

Sebagian besar responden beragama Islam yaitu 97 persen, sedangkan yang beragama Kristen ada sekitar 3 persen yang berada di kelurahan Tandang. Artinya bahwa sebagian besar warga miskin di Kota Semarang beragama Islam.

Mayoritas responden berstatus kawin, dengan rincian sebagai berikut: responden yang berstatus kawin ada sekitar 87 persen, janda sebanyak 9 persen dan tidak kawin sebanyak 4 persen. Dari empat kelurahan sampel tidak ditemukan status responden sebagai duda.

Pendidikan responden masih didominasi lulusan Sekolah Dasar (SD) yaitu mencapai 32 persen, sedangkan yang tidak amat SD ada sebanyak 25 persen, tidak tamat SMP ada 4 persen, tamat SMP ada 17 persen dan tamat SMA sebanyak 22 persen. Artinya ada 57 persen warga miskin di kota Semarang berpendidikan sangat rendah. Pendidikan yang rendah tentunya akan menyulitkan untuk mendapatkan pekerjaan dengan penghasilan yang layak. Responden yang tidak tamat SD hanya ada di kelurahan Tandang, yaitu 25 persen. Responden yang tamatan SMA sebanyak 18 persen ada di kelurahan Genuksari dan 4 persen ada di 
kelurahan Tandang.

Untuk masalah pekerjaan, responden sebagian besar bekerja sebagai buruh, yaitu 42 persen dengan penghasilan rata-rata per bulan sebesar Rp698.000,00 dan menanggung sebanyak 3 orang anggota keluarganya. Meskipun ada juga responden yang masih menganggur yaitu sebanyak 2 persen. Tanggungjawab untuk menghidupi keluarganya membuat warga miskin yang hanya berpendidikan setingkat SD berwiraswasta (22 persen) atau berdagang (17 persen). Berdasarkan hasil survei lapangan diketahui bahwa warga miskin di Kota Semarang yang bekerja sebagai petani hanya sebanyak 2 persen.

Di kelurahan Bubakan, respondennya termasuk keluarga besar dengan anggota rata-rata 4 jiwa, sedangkan di tiga kelurahan yang lain jumlah anggota keluarga rata-rata 3 jiwa. Secara rata-rata jumlah tanggungan setiap warga miskin di Kota Semarang adalah sebanyak 3 jiwa.

Selama dua tahun terakhir, ada sekitar 62

Tabel 9. Data Identitas Responden (Orang)

\begin{tabular}{|c|c|c|c|c|c|c|}
\hline \multirow[t]{2}{*}{ No } & \multirow[t]{2}{*}{ Kategori } & \multicolumn{4}{|c|}{ Kelurahan } & \multirow[t]{2}{*}{ Jumlah } \\
\hline & & Bubakan & Krobokan & Genuksari & Tandang & \\
\hline \multirow[t]{3}{*}{1.} & Jenis Kelamin & & & & & \\
\hline & - Laki-laki & 4 & 21 & 24 & 17 & 66 \\
\hline & - Perempuan & - & - & - & 34 & 34 \\
\hline \multirow[t]{3}{*}{2.} & Agama & & & & & \\
\hline & - Islam & 4 & 21 & 24 & 48 & 97 \\
\hline & - Kristen & - & - & - & 3 & 3 \\
\hline \multirow[t]{5}{*}{3.} & Status & & & & & \\
\hline & - Kawin & 1 & 14 & 24 & 48 & 87 \\
\hline & - Janda & 2 & 7 & - & - & 9 \\
\hline & - Duda & - & - & - & - & - \\
\hline & - Tidak kawin & 1 & - & - & 3 & 4 \\
\hline \multirow[t]{6}{*}{4.} & Pendidikan & & & & & \\
\hline & -Tidaktamat SD & - & - & - & 25 & 25 \\
\hline & $-\mathrm{SD}$ & 4 & 21 & 6 & 1 & 32 \\
\hline & -Tidaktamat SMP & - & - & - & 4 & 4 \\
\hline & $-\mathrm{SMP}$ & - & - & - & 17 & 17 \\
\hline & - SMA & - & - & 18 & 4 & 22 \\
\hline \multirow[t]{9}{*}{5.} & Pekerjaan & & & & & \\
\hline & - Pengangguran & - & - & - & 2 & 2 \\
\hline & - Sopir & - & - & - & 8 & 8 \\
\hline & - Swasta & 2 & - & 4 & 16 & 22 \\
\hline & - Buruh & 1 & 21 & 13 & 7 & 42 \\
\hline & - Bengkel & 1 & - & - & - & 1 \\
\hline & - Dagang & - & - & 4 & 13 & 17 \\
\hline & - Karyawan & - & - & 3 & 3 & 6 \\
\hline & - Tani & - & - & - & 2 & 2 \\
\hline \multirow[t]{2}{*}{6.} & Rata-rata (Rp) & & & & & \\
\hline & penghasilan/bulan & 650.000 & 908.000 & 603.000 & 665.000 & 698.000 \\
\hline \multirow[t]{2}{*}{7.} & Rerata (orang) & & & & & \\
\hline & tanggungan & 4 & 3 & 3 & 3 & 3 \\
\hline \multirow[t]{5}{*}{8.} & $\begin{array}{l}\text { Jml Jenis Bantuan } \\
\text { yg diterima }\end{array}$ & & & & & \\
\hline & - Tidak ada & 2 & 7 & 5 & 12 & 26 \\
\hline & - Satu (1) & 1 & 3 & 7 & 19 & 30 \\
\hline & - Dua (2) & 1 & 6 & 3 & 13 & 23 \\
\hline & - Tiga (3) & - & 5 & 9 & 7 & 21 \\
\hline \multicolumn{2}{|c|}{ Jumlah Responden } & 4 & 21 & 24 & 51 & 100 \\
\hline
\end{tabular}


persen warga miskin telah menerima bantuan yang berupa raskin, sedangkan BLT ada sekitar 44 persen dan 14 persen GPS. Ini menunjukkan bahwa tidak semua jenis bantuan bisa diterimakan kepada semua warga miskin yang ada di setiap kelurahan. Juga tidak semua jenis bantuan dapat disalurkan di setiap kelurahan di Kota Semarang. Contohnya jenis bantuan JPS, BKK, BKM dan sembako hanya ada di kelurahan Krobokan, sedangkan GPS ada di kelurahan Krobokan dan Genuksari. Jenis bantuan jamkesmas dan kompor gas telah diterimakan di kelurahan Krobokan dan Tandang. Sedangkan jenis bantuan yang ada di setiap kelurahan vaiti1 rackin dan $\mathrm{RI} T$ kah laku warga masyarakat bersumber pada suatu sistem nilai budaya yang dianut oleh warga masyarakat tersebut. Jika sistem nilai budaya yang dianut itu berorientasi pada pembangunan, maka sikap yang timbul kemudian adalah sikap mental yang positif, yaitu sikap mental yang mendukung upaya-upaya menuju peningkatan taraf hidup masyarakat. Sebaliknya, jika sistem nilai budayanya tidak berorientasi pada pembangunan, maka yang timbul kemudian adalah sikap mental negatif, yaitu sikap mental yang tidak mendukung upayaupaya menuju peningkatan taraf hidup masyarakat. Sikap mental yang disebut terakhir ini mamnı momnonorarıhi tinckat kamickinan
Orientasi Nilai Budaya dan Sikap Mental Responden

Pola-pola cara berpikir, bersikap, dan berting-


jaan sekitar 19 persen. Hampir 56 persen responden setuju bahwa untuk menghasilkan karya yang lebih baik diperlukan ijazah atau 
Tabel 10. Jawaban Responden tentang Hakekat Hidup Manusia

\begin{tabular}{lcccccccccccc}
\hline Kelurahan & \multicolumn{9}{c}{ A1 } & \multicolumn{9}{c}{ A2 } & \multicolumn{3}{c}{ A3 } & \multicolumn{3}{c}{ A4 } \\
\cline { 2 - 14 } & $\mathbf{a}$ & $\mathbf{b}$ & abst & $\mathbf{a}$ & $\mathbf{b}$ & abst & $\mathbf{a}$ & $\mathbf{b}$ & abst & $\mathbf{a}$ & $\mathbf{b}$ & abst \\
\hline Bubakan & 3 & 1 & - & 4 & - & - & 2 & 2 & - & 3 & 1 & - \\
Krobokan & 20 & 1 & - & 18 & 3 & - & 11 & 10 & - & 10 & 10 & 1 \\
Genuksari & 22 & 2 & - & 21 & 3 & - & 15 & 9 & - & 11 & 13 & - \\
Tandang & 44 & 7 & - & 45 & 6 & - & 23 & 28 & - & 17 & 34 & - \\
Jumlah & 89 & 11 & 0 & 88 & 12 & 0 & 51 & 49 & 0 & 41 & 58 & 1 \\
\hline
\end{tabular}

Sumber: Data primer

keahlian dan juga pengalaman. Sebaliknya, 44 persen responden sependapat bahwa dengan ijazah atau keahlian serta pengalaman dapat diperoleh uang sebanyak-banyaknya. Hal ini dapat diartikan bahwa orientasi karya bagi warga miskin relatif masih terbatas pada perolehan uang atau materi dan belum kepada hasil karya itu sendiri seperti penghargaan, kepuasan dan lain-lain.

Pandangan warga miskin terhadap karya kan dan merencanakan masa depannya sendiri. Namun ketika tiba pada pandangan yang mengatakan bahwa hari esok tidak perlu dikhawatirkan karena belum jelas keadaannya, hanya 18 persen dari responden yang sependapat. Sebagian besar warga miskin juga sepakat untuk hidup hemat dan menabung, yaitu 98 persen. Warga miskin lebih banyak menggunakan pendapatannya untuk membiayai sekolah anakanaknya dan mempersiapkan hari esok yang

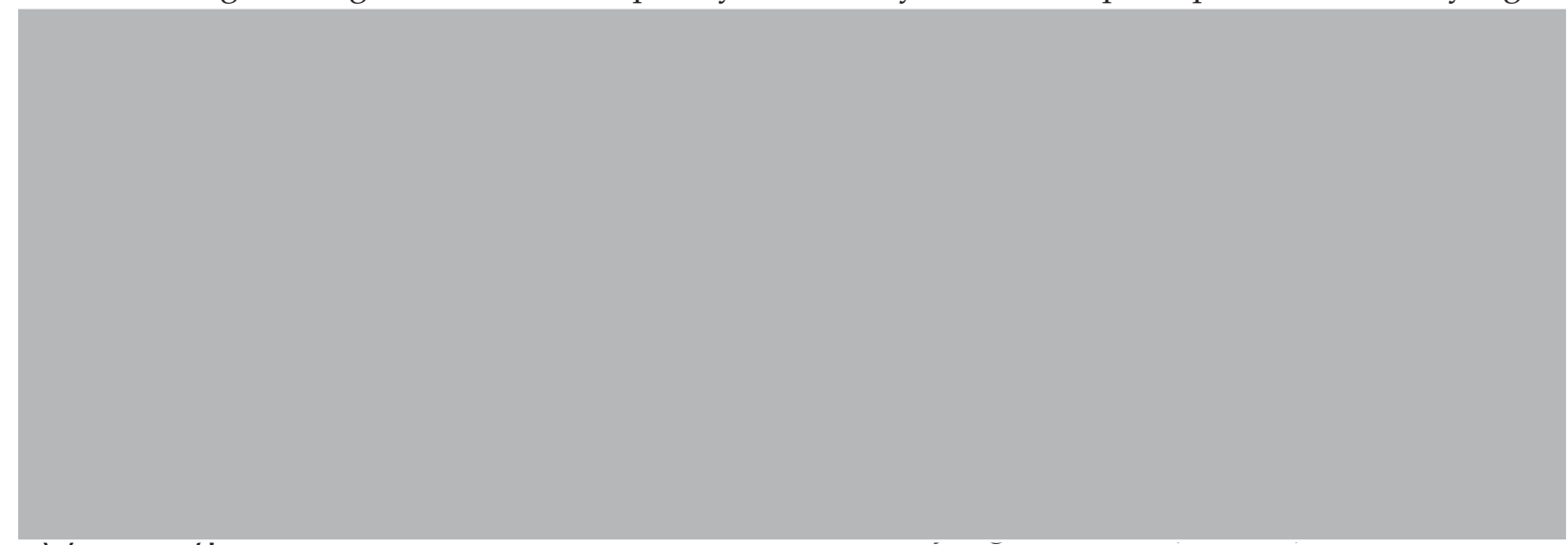

h’adap hakekat waktu, responden mempunyai orientasi nilai budaya yang positif. Sebanyak 82 persen dari total responden setuju terhadap pandangan bahwa manusia harus mempersiap-
(4) Tentang Hubungan dengan Alam. Demikian juga terhadap hakekat hubungan dengan alam, warga miskin mempunyai orientasi nilai budaya yang positif. Warga miskin menyatakan

Tabel 11. Jawaban Responden tentang Hakekat Karya Manusia

\begin{tabular}{|c|c|c|c|c|c|c|c|c|c|c|c|c|}
\hline \multirow[t]{2}{*}{ Kelurahan } & \multicolumn{3}{|c|}{ B1 } & \multicolumn{3}{|c|}{ B2 } & \multicolumn{3}{|c|}{ B3 } & \multicolumn{3}{|c|}{ B4 } \\
\hline & $\mathbf{a}$ & $\mathbf{b}$ & abst & $\mathbf{a}$ & $\mathbf{b}$ & abst & $\mathbf{a}$ & $\mathbf{b}$ & abst & $\mathbf{a}$ & $\mathbf{b}$ & abst \\
\hline Bubakan & 4 & - & - & 2 & 1 & 1 & 1 & 3 & - & 4 & - & - \\
\hline Krobokan & 12 & 9 & - & 19 & 2 & - & 11 & 9 & 1 & 15 & 6 & - \\
\hline Genuksari & 14 & 10 & - & 19 & 5 & - & 13 & 11 & - & 14 & 10 & - \\
\hline Tandang & 26 & 25 & - & 40 & 11 & - & 28 & 23 & - & 33 & 18 & - \\
\hline Jumlah & 56 & 44 & 0 & 80 & 19 & 1 & 53 & 46 & 1 & 66 & 34 & 0 \\
\hline
\end{tabular}

Sumber: Data primer 
Tabel 12. Jawaban Responden tentang Hakekat Waktu

\begin{tabular}{lcccccccccccc}
\hline \multirow{2}{*}{ Kelurahan } & \multicolumn{9}{c}{ C1 } & \multicolumn{9}{c}{ C2 } & \multicolumn{3}{c}{ C3 } & \multicolumn{3}{c}{ C4 } \\
\cline { 2 - 13 } & $\mathbf{a}$ & $\mathbf{b}$ & abst & $\mathbf{a}$ & $\mathbf{b}$ & abst & $\mathbf{a}$ & $\mathbf{b}$ & abst & $\mathbf{a}$ & $\mathbf{b}$ & abst \\
\hline Bubakan & 2 & 2 & - & 4 & - & - & 4 & - & - & 4 & - & - \\
Krobokan & 16 & 5 & - & 20 & 1 & - & 20 & - & 1 & 19 & 2 & - \\
Genuksari & 17 & 7 & - & 24 & - & - & 24 & - & - & 21 & 3 & - \\
Tandang & 47 & 4 & - & 50 & 1 & - & 51 & - & - & 43 & 8 & - \\
\hline Jumlah & 82 & 18 & 0 & 98 & 2 & 0 & 99 & 0 & 1 & 87 & 13 & 0
\end{tabular}

Sumber: Data primer

Tabel 13. Jawaban Responden tentang Hubungan dengan Alam

\begin{tabular}{lcccccccccccc}
\hline Kelurahan & \multicolumn{3}{c}{ D1 } & \multicolumn{3}{c}{ D2 } & \multicolumn{3}{c}{ D3 } & \multicolumn{3}{c}{ D4 } \\
\cline { 2 - 14 } & $\mathbf{a}$ & $\mathbf{b}$ & abst & $\mathbf{a}$ & $\mathbf{b}$ & abst & $\mathbf{a}$ & $\mathbf{b}$ & $\mathbf{a b s t}$ & $\mathbf{a}$ & $\mathbf{b}$ & abst \\
\hline Bubakan & 4 & - & - & 4 & - & - & 3 & 1 & - & 4 & - & - \\
Krobokan & 18 & 3 & - & 14 & 7 & - & 19 & 2 & - & 21 & - & - \\
Genuksari & 21 & 3 & - & 18 & 6 & - & 22 & 2 & - & 24 & - & - \\
Tandang & 37 & 14 & - & 47 & 4 & - & 46 & 5 & - & 50 & 1 & - \\
\hline Jumlah & 80 & 20 & 0 & 83 & 17 & 0 & 90 & 10 & 0 & 99 & 1 & 0 \\
\hline
\end{tabular}

Sumber: Data primer

perlunya mengolah alam untuk memenuhi kebutuhan hidupnya. Namun menurut warga miskin berhasil tidaknya usaha tersebut sangat tergantung pada usaha manusia itu sendiri, kondisi alam hanva membatasi usaha manusia terhadap kebersihan lingkungan tempat tinggalnya. Sehingga dengan keterbatasan dana yang dimilikinya, warga miskin tidak setuju jika kebersihan itu diserahkan kepada pihak lain dengan cara dibavar.

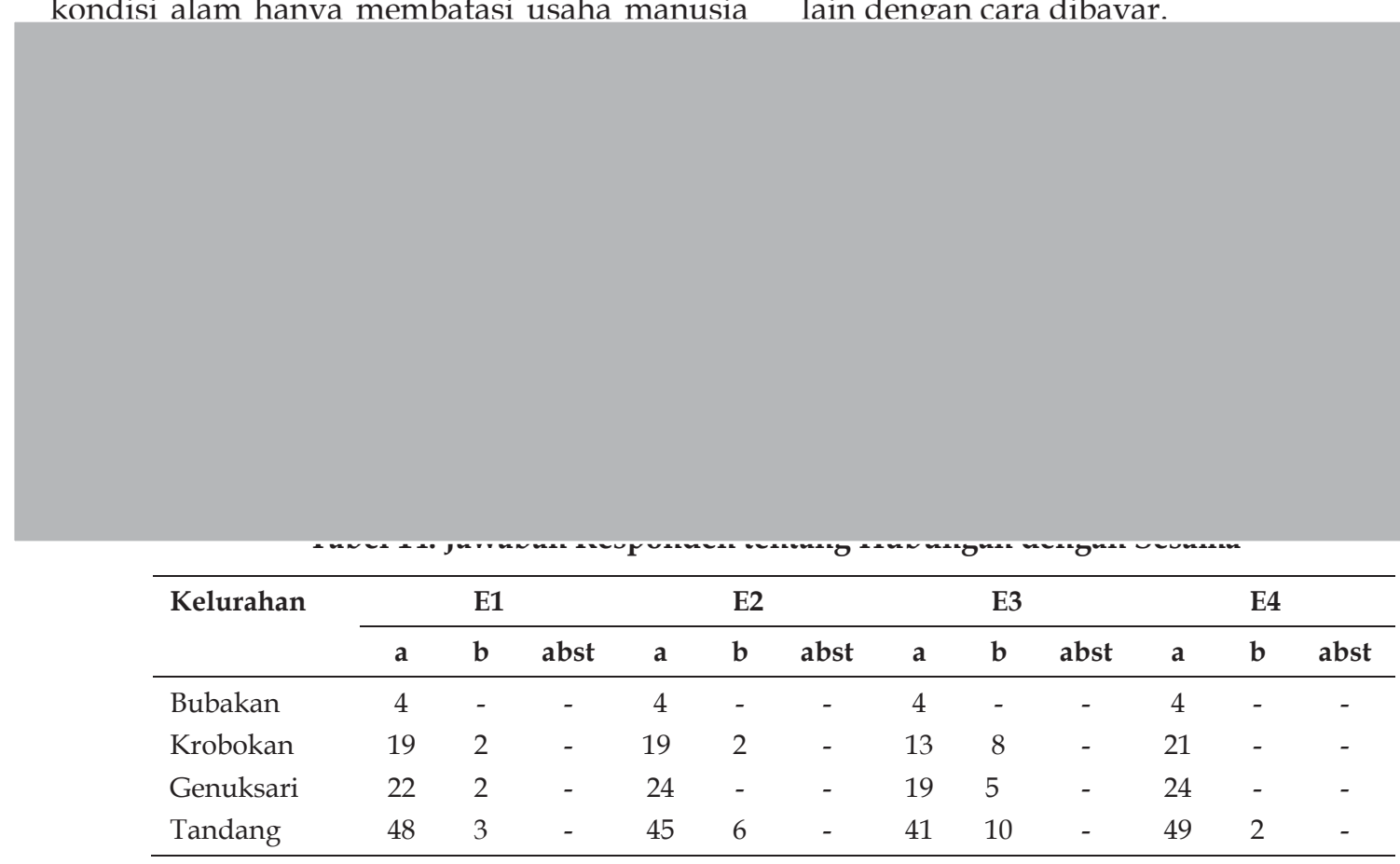

Sumber: Data primer 
inisiatif warga miskin dalam berupaya mengatasi setiap persoalan yang sedang dihadapinya. Warga miskin akan berinisiatif untuk melakukan usaha produktif yang diyakini akan meningkatkan kesejahteraan keluarga dan lingkungannya tanpa menunggu komando. Di samping itu warga miskin juga memiliki kesadaran tinggi untuk selalu bersosialisasi dengan masyarakat di lingkungannya.

\section{SIMPULAN}

Berdasarkan data yang diperoleh di lapangan dapat disimpulkan sebagai berikut: Pertama, ciri-ciri warga miskin di Kota Semarang antara lain, kepala rumah tangga sebagian besar berpendidikan rendah (tamat SD) dan mempunyai pekerjaan sebagai buruh, serta mempunyai tanggungan 3 jiwa. Kedua, bahwa terjadi ketidakmerataan dalam distribusi bantuan kepada warga miskin. Hal ini teridentifikasi dengan ditemukannya sekitar 26 persen warga miskin tidak pernah menerima bantuan jenis apapun selama dua tahun terakhir. Ketiga, warga miskin di Kota Semarang memiliki orientasi nilai budaya dan sikap mental yang positif dalam memandang hakekat hidup, hakekat karya, hakekat waktu, hakekat hubungan dengan alam semesta dan sesama manusia. Namun secara rata-rata jika dibuat peringkat maka orientasi nilai budaya dan sikap mental yang positif dengan mendapat point tertinggi adalah hakekat waktu (91 persen), kemudian diikuti hakekat hubungan dengan sesama manusia (90 persen), hakekat hubungan dengan alam (88 persen), hakekat hidup (67 persen) dan hakekat karya (64 persen).

Berdasarkan peringkat yang ada, maka bisa disimpulkan di sini bahwa: warga miskin di kota Semarang dalam mensikapi kondisinya, lebih berkeyakinan untuk mempersiapkan masa depannya dengan melakukan penghematan atau menabung. Kemudian warga miskin juga lebih percaya kepada kemampuannya sendiri tidak menggantungkan bantuan dari pihak/orang lain. Selain itu warga miskin harus bekerja mengolah alam untuk memenuhi kebutuhannya, karena warga miskin berkeyakinan bahwa mereka harus tetap berusaha meski dalam kekurangan, dan dengan berkarya akan diperoleh penghasilan untuk mencukupi kebutuhan hidupnya.

\section{DAFTAR PUSTAKA}

Bayo Ala, A. 1981. Strategi Anti Kemiskinan Lima Tahap. Analisa No.9, Tahun X, September 1981. Jakarta: CSIS.

Jogiyanto, HM. 2008. Pedoman Survei Kuesioner: Mengembangkan Kuesioner, Mengatasi Bias dan Meningkatkan Respon. Jogjakarta: BPFE - FEB UGM.

Koentjaraningrat. 1983. Kebudayaan, Mentalitet dan Pembangunan. Jakarta: Gramedia.

Muslow, A.H. 1984. Motivasi dan Kepribadian. Jakarta: PT. Pustaka Binama Pressindo.

Kuncoro, Mudrajat. 2000. Ekonomi Pembangunan, Teori, Masalah dan Kebijakan. Jogjakarta: BPFE-UGM.

Prastowo, Andi. 2010. Menguasai Teknik-Teknik Koleksi Data Penelitian Kualitatif. Jogjakarta: Diva Press.

Sajogyo. 1977. Garis Kemiskinan dan Kebutuhan Pokok. Bogor: LPSP-IPB.

Sajogyo, Lala M Kolopaking, dan Sumardjo. 1983. Profil Rumah tangga Pertanian Tanaman Pangan, Perikanan Darat dan Perariran Umum dan Peternakan dalam Sensus Pertanian 1983. Jakarta: BPS.

Sutikno, dkk. 2009. Pemilihan Program Pengentasan Kemiskinan Melalui Pengembangan Model Pemberdayaan Masyarakat dengan Pendekatan Sistem, Jurnal Ekonomi Pembangunan Vol.11 No.1 Juni 2010:135.

Tjiptoherijanto, Prijono dan Sutyastie Soemitro. 1997. Sumber Daya Manusia dalam Pembangunan Nasional. Jakarta: FE UI.

Tjiptoherijanto, Prijono dan Sutyastie Soemitro. 1998. Pemberdayaan Penduduk dan Peningkatan Kualitas Sumber Daya Manusia. Jakarta: PT. Cita Putra Bangsa 


\section{LAMPIRAN A}

\section{Orientasi Nilai Budaya dan Sikap Mental}

A. Tentang hakekat hidup manusia:

1. (a) Kaya atau miskin memang sudah menjadi ketetapan Allah, namun demikian manusia tetap diwajibkan berusaha. (b) Kaya atau miskin memang sudah menjadi ketetapan Allah, karena itu manusia tidak perlu susah payah memikirnya.

2. (a) Hari esok harus lebih baik dari hari ini. (b) Melihat keadaan seperti sekarang, saya tidak bisa membayangkan nasib keluarga saya nantinya.

3. (a) Selalu melakukan perbaikan kualitas hidup secara berkelanjutan. (b) Menerima keadaan hidup sekarang ini dengan apa adanya.

4. (a) Secara aktif terlibat dalam setiap aktivitas-aktivitas yang berkaitan dengan peningkatan hidup (misal: pelatihan atau kursus yang diadakan kelurahan). (b) Merasa minder dan tidak bisa mengikuti pelatihan atau kursus yang diselenggarakan oleh kelurahan.

B. Tentang hakekat karya manusia :

1. (a) Dengan ijazah atau keahlian dan pengalaman yang dimiliki, kita dapat menghasilkan karya yang lebih baik. (b) Dengan ijazah atau keahlian dan pengalaman yang dimiliki, kita dapat memperoleh uang sebanyak-banyaknya.

2. (a) Walaupun hasil panen sekarang (penghasilan sekarang) sudah cukup baik, saya akan terus berusaha agar hasilnya lebih baik lagi. (b) Yang penting pekerjaan itu ada dan memberikan hasil, mengenai mutunya tidak usah dipikirkan dulu.

3. (a) Dari hasil panen nanti (penghasilan nanti) saya akan mengembangkan usaha di bidang lain (misal perikanan, peternakan, dagang, dan lain-lain).

b. Bagi saya saat ini, keluarga bisa makan dan tidak ada hutang, saya sudah puas.

4. (a) Berdasarkan penghasilan sekarang, masih perlu kerja ekstra untuk menambah penghasilan. (b) Bagi saya penghasilan sekarang adalah sebagai jatah dari yang Maha Kuasa, jadi ya harus dicukupkan dengan kebutuhan kita.

C. Tentang hakekat waktu:

1. (a) Manusia harus mempersiapkan dan merencanakan masa depannya sendiri. (b) Hari esok tidak perlu dikhawatirkan sebab belum jelas keadaannya.

2. (a) Kita harus hidup hemat agar dapat menabung untuk memupuk modal, membiayai sekolah anak-anak dan mempersiapkan hari esok yang lebih baik. (b) Tabungan itu perlu untuk persiapan kalau mau mengadakan pesta (perkawinan, khitanan, dan lain-lain) atau pergi "kondangan"

3. (a) Pesta perkawinan itu tidak perlu mewah, yang penting aqad nikahnya. (b) Pesta perkawinan itu harus mewah agar lebih meriah, mengenai biaya bisa pinjam dulu dengan saudara atau tetangga.

4. (a) Hidup sepertinya berpacu dengan waktu, maka kita harus mengisi waktu kita dengan kualitas hidup yang selalu baik. (b) Hidup ini bagaikan pangung sandiwara, maka kita hanya berlaku seadanya saja atau monoton.

D. Tentang hubungan dengan alam:

1. (a) Setiap orang harus mengolah alam untuk memenuhi kebutuhan hidupnya. (b) Swasembada beras yang telah dicapai selama ini disebabkan suburnya alam Indonesia.

2. (a) Dengan ilmu pengetahuan dan teknologi budidaya pertanian akan selalu mengalami kemajuan, karena itu kita harus selalu memperbaiki cara kita berusaha tani. (b) Kita harus memperta-hankan cara-cara berusaha tani yang telah diajarkan oleh orang tua, kita tidak perlu mencoba teknologi baru.

3. (a) Teknologi pertanian bertujuan untuk meningkatkan kesejahteraan hidup petani. (b) Teknologi pertanian hanya menguntungkan petani kaya saja. 
4. (a) Setiap orang harus ikut menjaga kebersihan lingkungan tempat tinggalnya. (b) Kebersihan lingkungan diserahkan saja pada orang lain, karena kita sudah bayar.

E. Tentang hubungannya dengan sesama:

1. (a) Percaya pada kemampuan diri sendiri merupakan kunci keberhasilan. (b) Keberhasilan dan kegagalan kita ditentukan juga oleh keberhasilan dan kegagalan orang-orang di sekitar kita.

2. (a) Kalau mengalami kegagalan dalam usaha, kita harus berusaha memperbaikinya sendiri dan jangan menunggu bantuan dari orang lain. (b) Selama masih ada hubungan baik dengan tetangga, kita tidak perlu khawatir dengan masa depan kita.

3. (a) Kalau varitas itu lebih unggul dari yang lama, sebagai petani, saya pasti akan menanamnya, walaupun tidak diwajibkan pemerintah. (b) Saya tidak menjadi anggota kelompok tani karena tetangga saya juga tidak ada yang ikut.

4. (a) Kalau ada acara kerja bakti, saya pasti ikut, walaupun tidak diwajibkan oleh Pak Lurah/RT. (b) Saya tidak ikut kerjabakti, karena bisa digantikan dengan uang.

\section{LAMPIRAN B}

Tabel 15. Hubungan Orientasi Nilai Budaya dan Sikap Mental terhadap Lima Masalah Dasar Manusia

\begin{tabular}{|c|c|c|c|c|}
\hline Sikap Mental Negatif & $\begin{array}{l}\text { Orientasi Nilai } \\
\text { Budaya Manusia }\end{array}$ & Masalah Dasar & $\begin{array}{l}\text { Orientasi } \\
\text { Nilai Budaya }\end{array}$ & $\begin{array}{l}\text { Sikap Mental } \\
\text { Positif }\end{array}$ \\
\hline Fatalis & $\begin{array}{l}\text { Hidup buruk dan } \\
\text { tidak ada usaha agar } \\
\text { menjadi baik }\end{array}$ & $\begin{array}{l}\text { Hakekat hidup } \\
(\mathrm{HH})\end{array}$ & $\begin{array}{l}\text { Hidup buruk } \\
\text { tapi manusia } \\
\text { wajib berusaha } \\
\text { menjadi baik }\end{array}$ & Optimis \\
\hline Cepat merasa puas & $\begin{array}{l}\text { Karya untuk nafkah } \\
\text { hidup }\end{array}$ & $\begin{array}{l}\text { Hakekat karya } \\
(\mathrm{HK})\end{array}$ & $\begin{array}{l}\text { Karya untuk } \\
\text { menambah } \\
\text { karya }\end{array}$ & $\begin{array}{l}\text { Selalu ingin ber- } \\
\text { prestasi }\end{array}$ \\
\hline Boros & Masa kini & $\begin{array}{l}\text { Hakekat waktu } \\
(\mathrm{HW})\end{array}$ & Masa depan & Hemat \\
\hline $\begin{array}{l}\text { Sukar menerima } \\
\text { inovasi }\end{array}$ & Tunduk pada alam & $\begin{array}{l}\text { Hakekat } \\
\text { hubungan dengan } \\
\text { alam (HA) }\end{array}$ & $\begin{array}{l}\text { Berhasrat } \\
\text { menguasai alam }\end{array}$ & $\begin{array}{l}\text { Cepat menerima } \\
\text { inovasi }\end{array}$ \\
\hline $\begin{array}{l}\text { Rasa ketergantungan } \\
\text { pada sesama besar }\end{array}$ & Konformis & $\begin{array}{l}\text { Hakekat } \\
\text { hubungan dengan } \\
\text { sesama }(\mathrm{HM})\end{array}$ & Individualis & $\begin{array}{l}\text { Menilai tinggi usaha } \\
\text { atas kekuatan } \\
\text { sendiri }\end{array}$ \\
\hline
\end{tabular}

